\title{
Omeprazole inhibits acetylsalicylic acid-modified histamine stimulation of acid secretion in rabbit gastric glands
}

DANIEL T BROSSEUK MD, IAIN GM CLEATOR MB ChB FRCSC FRCSE FRCS FACS, ANDREW J RAE BSc MCS, GILBERT WANKLING MD

DT BRosseuk, IGM Cleator, AJ RAE, G WANKLING. Omeprazole inhibits acetylsalicylic acid-modified histamine stimulation of acid secretion in rabbit gastric glands. Can J Gastroenterol 1994;8(1):15-20. The effects of misoprostol and omeprazole on basal-, histamine- and acetylsalicylic acid (ASA)-induced gastric acid secretion by isolated rabbit gastric glands were studied. The authors found that ASA at a concentration of $2.4 \times 10^{-3} \mathrm{M}$ significantly inhibited acid secretion in the isolated gastric glands to $65 \%$ of basal levels, and that ASA at a concentration of $2.4 \times 10^{-2} \mathrm{M}$ significantly inhibited the histamine stimulation of acid secretion to $78 \%$ of maximal. Misoprostol inhibited acid secretion to $76 \%$ of basal acid secretion, while omeprazole inhibited secretion to $58 \%$ of basal values. Misoprostol inhibited the ASA-modified histamine stimulation to $82 \%$ of maximal stimulation. In contrast, omeprazole was able to inhibit the ASA-modified histamine stimulation to $48 \%$ of maximal. This omeprazole inhibition of secretagogue-induced acid production reduced acid secretion to levels below basal secretion, indicating that neither histamine nor ASA (at the concentrations used), alone or in combination, had any stimulatory effect in the presence of omeprazole. Misoprostol is the recommended drug of choice for prevention and treatment of nonsteroidal anti-inflammatory drug (NSAID)-induced gastrointestinal mucosal injury. In vitro results suggest that omeprazole appears to treat this condition more effectively if gastric acid secretion is a necessary prerequisite for NSAID-induced mucosal injury.

Key Words: Acid secretion, Gastric gland, Misoprostol, Nonsteroidal anti-inflammatory drug (NSAID), Omeprazole

L'oméprazole inhibe la stimulation de la sécrétion acide par la glande gastrique chez lapin provoquée par l'histamine modifiée par l'acide acétylsalicylique

RÉSUMÉ : Les effets du misoprostol et de l'oméprazole sur les sécrétions d'acide gastrique basales, induites par l'histamine et par l'acide acétylsalicylique (AAS)

Gastrointestinal Research Laboratory, Department of Surgery, St Paul's Hospital,

Vancouver, British Columbia

Correspondence: Dr IGM Cleator, \#374 Comox Building, 1081 Burrard Street, Vancouver, British Columbia V6Z IY6. Telephone (604) 681-1513, Fax (604) 631-5418

Received for publication June 4, 1993. Accepted August 30, 1993
Jonsteroidal anti-inflamma. tory drug (NSAID)-induced gastrointestinal mucosal injury can range from mild gastritis to frank peptic ulceration. NSAIDs in general, and acetylsalicylic acid (ASA) in particular, are extremely commonly ingested drugs used to treat conditions ranging from arthritis to vascular occlusive diseases, in addition to their use as analgesics. This widespread use of NSAIDs and the high associated incidence of NSAID-induced mucosal damage (1) means that this condition is frequently encountered by anyone dealing with gastrointestinal disorders. Misoprostol, a prostaglandin $E_{1}$ analogue, is the present drug of choice for prevention of this NSAID-induced damage. Misoprostol has been shown to exert its action on the Gi-subunit of the adenylate cyclase coupled to histamine- $\mathrm{H}_{2}$ receptor in rabbit parietal cells (2). Omeprazole is a newer drug in the armamentarium of treatment modalities for gastrointestinal mucosal injury; it exerts its effect at the level of the final common pathway for gastric acid secretion - the proton pump (3). Previous studies in vivo have indicated that omeprazole may be protective against NSAID-induced gastric mucosal damage $(4,5)$. We hypothesized that if ASA-induced gastric 
au niveau des glandes gastriques de lapins ont été étudiés. Les auteurs ont découvert que l'AAS, à une concentration de $2,4 \times 10^{-3} \mathrm{M}$ inhibait de façon significative la sécrétion acide au niveau des glandes gastriques isolées pour donner $65 \%$ des taux de base et qu'à une concentration de $2,4 \times 10^{-2} \mathrm{M}$, il inhibait de façon significative la stimulation par histamine de la sécrétion acide pour donner $78 \%$ des valeurs maximales. Le misoprostol a inhibé la sécrétion acide pour donner $75 \%$ de la sécrétion acide de base, alors que l'oméprazole a inhibé la sécrétion pour donner $58 \%$ des valeurs de base. Le misoprostol a inhibé la stimulation par l'histamine modifiée par l'AAS pour donner $82 \%$ de la stimulation maximale. Par ailleurs, l'oméprazole a pu inhiber la stimulation par l'histamine modifiée par l'AAS pour donner $48 \%$ des valeurs maximales. Cet effet inhibiteur de l'oméprazole sur la production d'acide par le sécrétagogue a réduit la sécrétion d'acide pour donner des taux inférieurs à la sécrétion basale indiquant ainsi que ni l'histamine, ni l'AAS (aux concentrations utilisées) seuls ou en association, n'ont pu exercer un effet stimulant en présence de l'oméprazole. Le misoprostol est le médicament de choix, recommandé pour la prévention et le traitement des lésions de la muqueuse digestive associées aux anti-inflammatoires non stéroïdiens (AINS). Selon les résultats in vitro, l'oméprazole semble traiter cette affection plus efficacement si la sécrétion d'acide gastrique est une composante de la lésion muqueuse induite par les AINS.

mucosal injury requires an acidic gastric environment, omeprazole should be able to inhibit this injury through its blockade of the proton pump, and we should be able to show inhibition of acid secretion in the presence of ASA in vitro. We chose isolated rabbit gastric glands as our model to study this hypothesis.

\section{MATERIALS AND METHODS}

Gastric glands were obtained in a fashion similar to the method established by Berglindh and Obrink (6). The study protocol was approved by the University of British Columbia Animal Care Committee. New Zealand white rabbits were heparinized and anesthetized with ketamine and xylazine. The stomach was perfused via a catheter inserted through the abdominal aorta with clamping of the supradiaphragmatic aorta to isolate perfusion to the upper abdominal organs. The perfusate was a phosphate-buffered saline solution (149.6 mM sodium chloride, 3.0 $\mathrm{mM}$ dipotassium hydrogen phosphate, $0.64 \mathrm{mM}$ sodium biphosphate monohydrate, $\mathrm{pH}$ 7.4) which caused edema of the gastric wall to enhance separation of the gastric mucosa. The antrum was then excised from the stomach and gastric mucosa was harvested through blunt dissection. After mechanical mincing, mucosa was digested in an oxygenated collagenase solution (130.0
$\mathrm{mM}$ sodium chloride, $12.0 \mathrm{mM}$ sodium bicarbonate, $3.0 \mathrm{mM}$ sodium biphosphate monohydrate, $3.0 \mathrm{mM}$ sodium phosphate dibasic, $3.0 \mathrm{mM}$ dipotassium hydrogen phosphate, $2.0 \mathrm{mM}$ magnesium sulphate, $1.0 \mathrm{mM}$ calcium chloride, $5.0 \mathrm{mg} / \mathrm{L}$ phenol red, $1.0 \mathrm{mg} / 10$ $\mathrm{mL}$ collagenase [Sigma type 1, Missouri], $1.5 \mathrm{mg} / 10 \mathrm{~mL}$ albumin, 1.5 $\mathrm{mg} / 10 \mathrm{~mL}$ glucose) for $60 \mathrm{mins}$. During this incubation and subsequent incubations, water bath temperatures remained at $37^{\circ} \mathrm{C}$ and a $\mathrm{pH}$ of 7.4 was maintained. Following collagenase digestion, the collagenase-enzyme solution and gastric glands were filtered through $170 \mu \mathrm{M}$ pores to remove large debris. Glands were rinsed in respiratory medium (132.4 mM sodium chloride, $5.4 \mathrm{mM}$ potassium chloride, 5.0 $\mathrm{mM}$ sodium phosphate dibasic, $1.0 \mathrm{mM}$ sodium biphosphate monohydrate, 1.2 $\mathrm{mM}$ magnesium sulphate, $1.0 \mathrm{mM}$ calcium chloride, $5 \mathrm{mg} / \mathrm{L}$ phenol red, 2.0 $\mathrm{mg} / 10 \mathrm{~mL}$ albumin, $2.0 \mathrm{mg} / 10 \mathrm{~mL}$ glucose). At this stage, glands were permitted to settle, supernatant was poured off and glands were resuspended in $30 \mathrm{~mL}$ of respiratory medium containing $0.11 \mathrm{~mL}(0.2 \mathrm{MBq})$ of $\mathrm{C}-14$ aminopyrine (Amersham) in solution. A second incubation of these glands in the combined aminopyrine/respiratory medium took place over 30 mins. During the two incubations, a 96-well tray was prepared for the final step in the experiment. Each well was filled with $170 \mu \mathrm{L}$ of respiratory medium and a 15 $\mu \mathrm{L}$ solution of each secretagogue or inhibitor, or combination of these substances, assigned to the particular well. In this series of experiments, $1.0 \times 10^{-4}$ $\mathrm{M}$ histamine (Sigma), $1.8 \times 10^{-6} \mathrm{M} \mathrm{mi}$ soprostol (Searle Canada), $1.9 \times 10^{-4} \mathrm{M}$ omeprazole (Astra Pharma) and $2.4 \times 10^{-4} \mathrm{M}$ ASA were used.

In a secondary experiment, ASA in concentrations of $2.4 \times 10^{-3} \mathrm{M}$ and $2.4 \times 10^{-2} \mathrm{M}$ were used to analyze the effect of increasing ASA dosing. Upon completion of a second incubation, $100 \mu \mathrm{L}$ of cell solution was added to each well, according to Adrian's micromethod (7). A third and final incubation involving placing the incubation chamber housing the microtitre plate into a water bath was performed for 60 mins. Flow rate of oxygen through the chamber was $3 \mathrm{~L} / \mathrm{min}$. Following incubation, the microtitre plate was placed on a vacuum filtration unit for 3 to $4 \mathrm{mins}$ to remove the supernatant. Any wells that did not adequately filter through due to an excess of cellular debris were discarded and not included in any subsequent analysis. Filters in each well were dried and then punched into scintillation vials. Ten millilitres of Ecolite(+) (ICN Biochemicals) scintillant was added to each vial and beta counting was performed for 5 mins (Beckman LS7500).

In the second set of experiments to analyze the effects of increasing concentrations of ASA, a separate batch of scintillant was used and beta counting was performed on a separate beta counter. Uptake of aminopyrine into the parietal cell estimates acid secretion (6) and, in turn, indicates the secretory effect of secretagogues and acidinhibiting drugs upon these cells.

\section{STATISTICS}

Differences between drug effects were determined by calculating weighted comparisons between the mean response across animals. The average value for each animal was estimated as the mean of all wells from that subject (typically seven to nine wells). These values were weighted to the between well variation for each animal. 


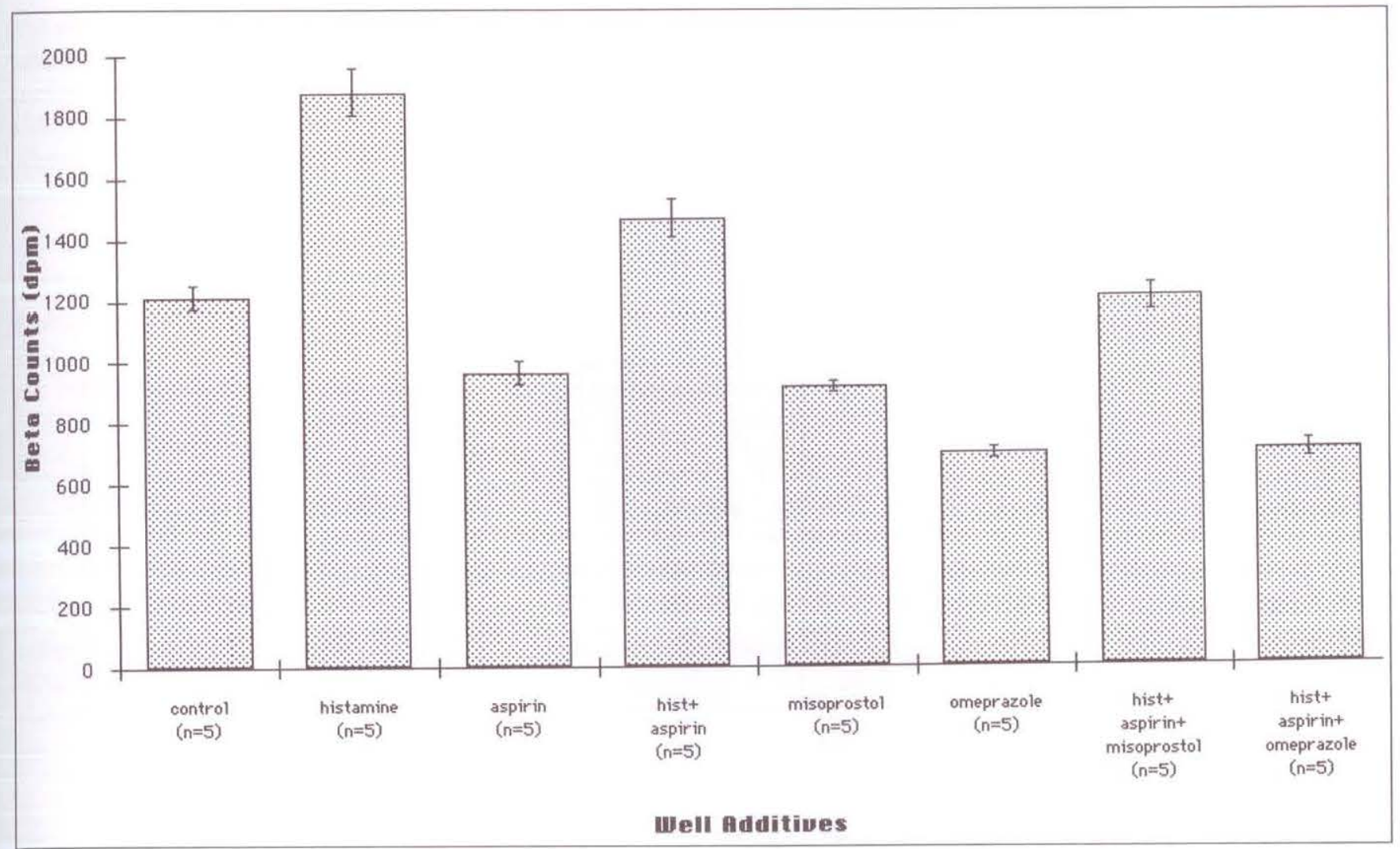

Figure 1) Decays per minute (dpm) of C-14 aminopyrine in isolated rabbit gastric glands as a measure of acid secretion. Values are given as an average of all wells in each category ( $n=5$ animals). Histamine was added as $1.0 \times 10^{-4} \mathrm{M}$, acetylsalicylic acid as $2.4 \times 10^{-4} \mathrm{M}$, omeprazole as $1.9 \times 10^{-4} \mathrm{M}$ and misoprostol as $1.8 \times 10^{-6} \mathrm{M}$

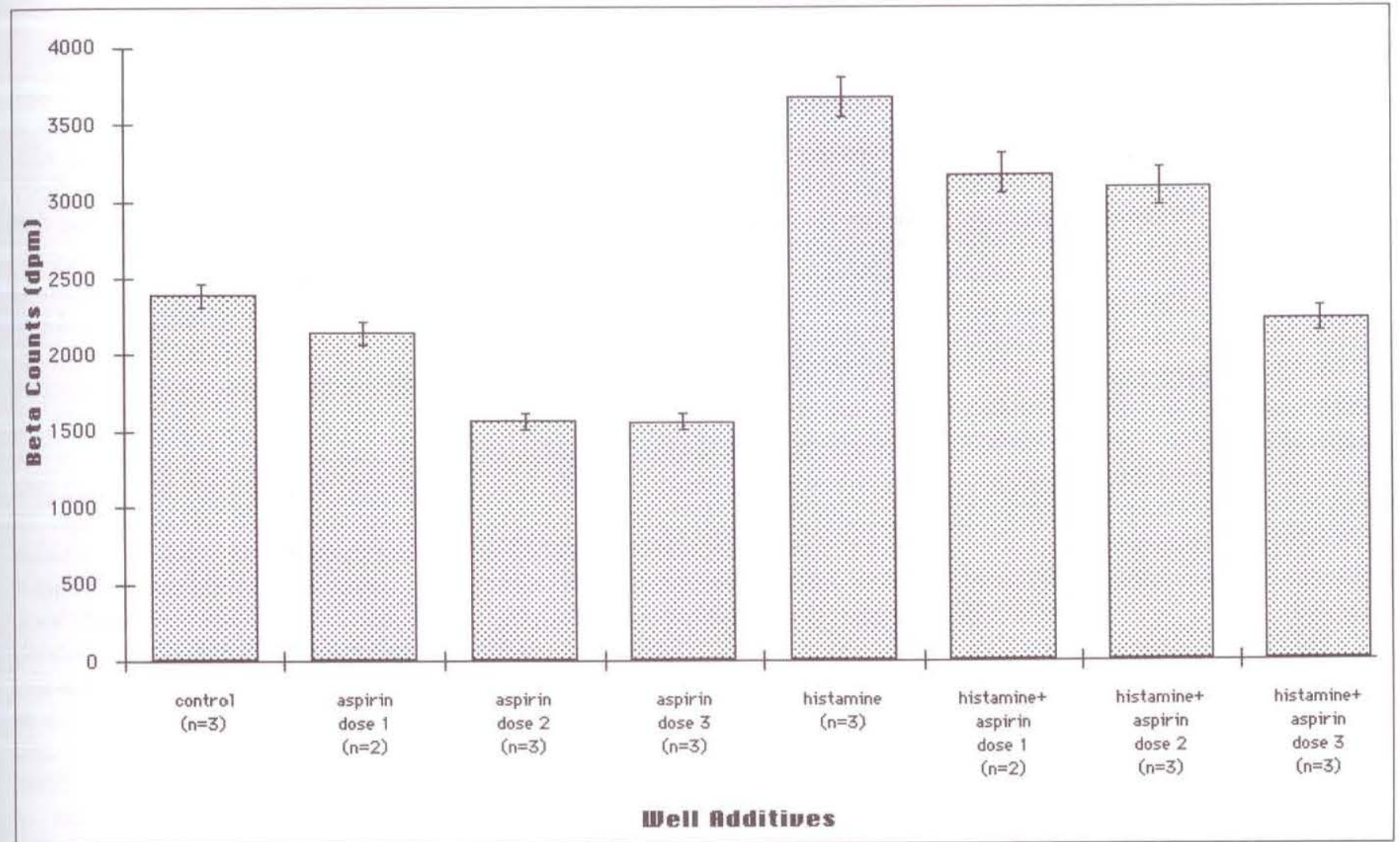

Figure 2) Inhibition of acid secretion in isolated rabbit gastric glands by increasing concentrations of acetylsalicylic acid ('aspirin' in the figure). Aspirin dose 1 is $2.4 \times 10^{-4} \mathrm{M}$, dose 2 is $2.4 \times 10^{-3} \mathrm{M}$ and dose 3 is $2.4 \times 10^{-2} \mathrm{M}$. Inhibition at dose 2 is statistically significant without the presence of histamine, and inhibition at dose 3 is statistically significant in the presence of histamine stimulation. dpm Decays per minute 


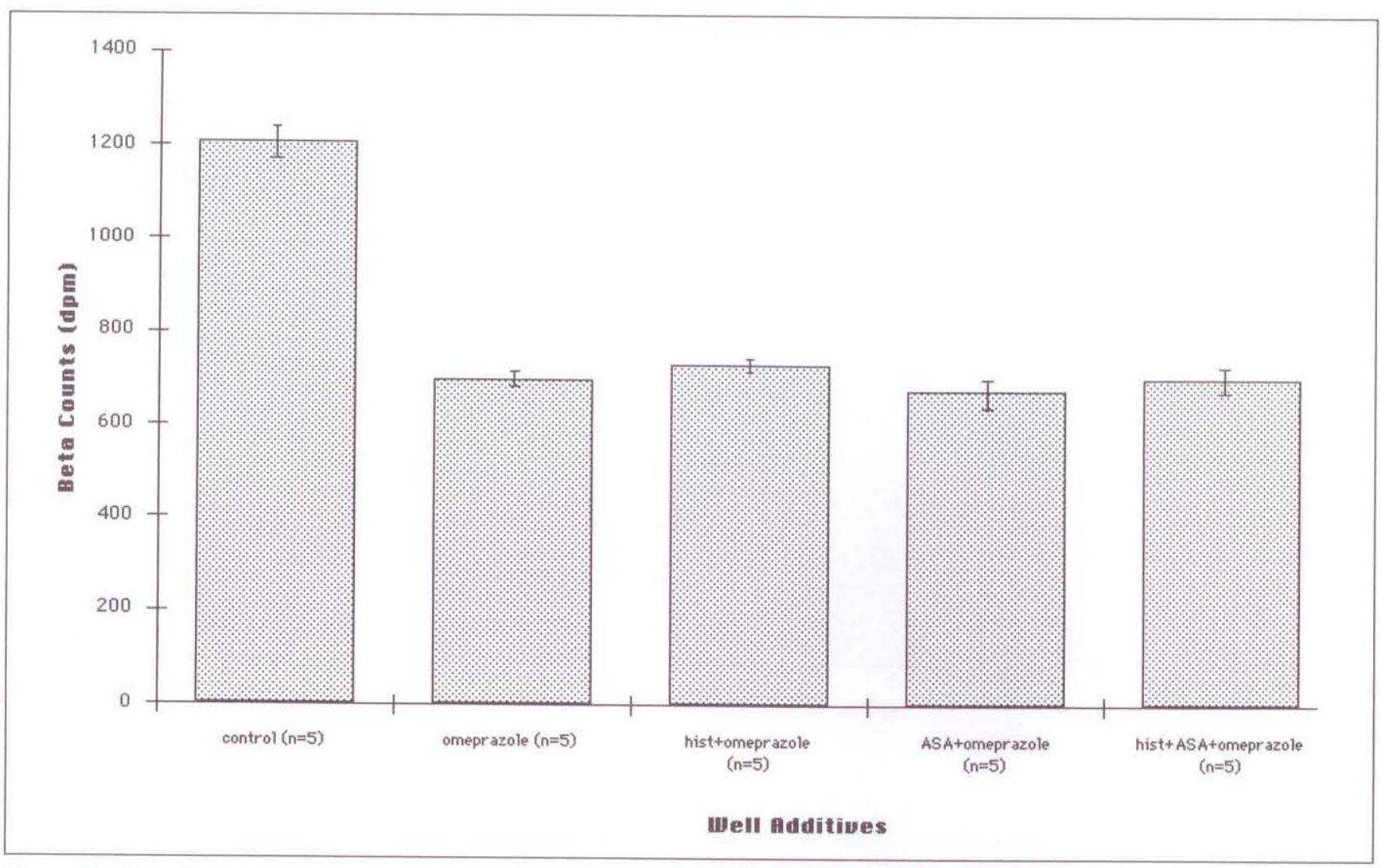

Figure 3) Effect of omeprazole on secretagogue activity of histamine and acetylsalicylic acid ('aspirin' in the figure) on isolated rabbit gastric glands as reflected by C-14 aminopyrine decay. There is no statistically significant difference in the inhibition shown by the omeprazole alone compared with any combination of omeprazole, histamine and acetylsalicylic acid. dpm Decays per minute

The weighted estimates were used to compute 95 to $99 \%$ confidence intervals about the mean response. Tighter confidence intervals were obtained to correct for multiple comparisons. Significant differences were assumed when confidence intervals did not overlap $(\mathrm{P}<0.05)$.

\section{RESULTS}

The wells belonging to the control group produced a mean count of 1206.6 \pm 32.1 decays per minute (dpm). These decay values were counted for 5 mins and then averaged. Figure 1 shows that addition of histamine significantly increased the beta count to $1873.4 \pm 60.4 \mathrm{dpm}$, representing a $55 \%$ increase in acid secretion above baseline. Addition of ASA alone had an inhibitory effect on the wells that was not significant at a concentration of $2.4 \times 10^{-4} \mathrm{M}$, but that, in a subsequent experiment to analyze the effect of increasing concentrations of ASA, was a significant inhibitor at a concentration of $2.4 \times 10^{-3} \mathrm{M}$ (Figure 2). It is of note that this second set of experiments used a separate batch of scintillant and a separate beta counter which resulted in across-the-board higher beta counts in the second set of experiments compared with the first (eg, control counts of 2391.8 versus 1206.6). This does not, however, affect the comparisons being made within each set of experiments. When ASA and histamine were added to the cells, there was an inhibition of the histamine stimulation with beta counts of $1465.1 \pm 47.5 \mathrm{dpm}$; this represents a decreased acid secretion of $12 \%$ below stimulation of histamine alone (Figure 1) which is not statistically significant, but which, once again, in subsequent experiments was found to be significant inhibition with a concentration of $2.4 \times 10^{-2} \mathrm{M}$ (Figure 2).

Misoprostol added to the cells produced a significant inhibitory effect with beta counts of $913.9 \pm 14.1 \mathrm{dpm}$, a $24 \%$ decrease in acid secretion below baseline. Omeprazole significantly in- hibited acid secretion by $42 \%$ below basal levels, producing beta counts of $696.3 \pm 16.9 \mathrm{dpm}$ (Figure 1). The inhibition by omeprazole is a statistically significant better inhibition than that shown by misoprostol. When misoprostol was added to the wells containing both ASA and histamine, it produced beta counts of $1204.2 \pm 30.55 \mathrm{dpm}$, a significant $18 \%$ reduction in acid secretion below the maximal levels. Omeprazole was able to inhibit the maximal secretion by $52 \%$, with beta counts of $702.2 \pm 20.4 \mathrm{dpm}$ (Figure 1). Once again the increase in inhibition by omeprazole compared with misoprostol attained statistical significance. This inhibition by omeprazole on wells containing both ASA and histamine produced virtually the same result as when omeprazole was added to cells being stimulated by histamine alone, which resulted in beta counts of $731.6 \pm 24.5 \mathrm{dpm}$ (Figure 3). Thus, the greatest inhibition of unmodified, and - of particular interest to our study - 
ASA-modified acid secretion, was exhibited by omeprazole at the concentrations that we tested. Regardless of additives, omeprazole consistently inhibited acid secretion to about $700 \mathrm{dpm}$ readings.

\section{DISCUSSION}

Misoprostol has been shown in a double-blind, placebo controlled trial to prevent NSAID-induced gastric ulcer (8). Misoprostol is also noted to be effective in the prevention of NSAID-induced duodenal ulceration (9). Although $\mathrm{H}_{2}$-receptor antagonists have been shown to have some role in the prevention of NSAID-induced duodenal ulceration (10), no other agent has been proven to be as effective as misoprostol in the prevention of NSAID-induced gastric and duodenal ulceration. It has been suggested that the pathogenesis of gastroduodenal lesions by ASA and other NSAIDs involves the back diffusion of hydrogen ions (11); if this is correct, any agent that maximally inhibits the production of hydrogen ions should be a very useful agent for the prevention and treatment of these lesions.

Omeprazole, a substituted benzimidazole, is a potent inhibitor of both histaminic and cholinergic stimulation of acid secretion by gastric parietal cells (3). Romano and colleagues (12) have demonstrated that omeprazole may also have a protective effect on gastric cells independent of inhibition of gastric acid secretion. Konturek (13) showed that this cytoprotective effect of omeprazole extends to gastric lesions induced specifically by ASA. It has not been previously demonstrated that omeprazole can inhibit acid secretion in the presence of ASA, in addition to any direct cytoprotection it affords against the ASA effect.

The literature contains contradictory reports on the effect that ASA has on gastric acid secretion, with different investigators suggesting there is no effect, stimulation and inhibition of acid secretion by ASA.

Levine et al (14) have suggested that ASA does not affect basal acid secretion, but may potentiate the secretagogue stimulation of acid secretion by gastric parietal cells. In our experiment, using a refined model of isolated rabbit gastric glands, we have confirmed the finding that a low concentration of ASA does not alter baseline acid secretion; in addition, we found that ASA at higher concentrations actually inhibits basal acid secretion. These results are in agreement with the findings of SheaDonahue and co-workers (15) who showed in vivo that ASA inhibits $\mathrm{H}^{+}$ secretion in rhesus monkeys. These investigators speculated that this inhibition in vivo may be due to a combination of the back diffusion of $\mathrm{H}^{+}$into the cells following ASA-induced mucosal injury and a direct inhibitory action of ASA on the parietal cells.

Levine and colleagues (14) demonstrated ASA potentiation of histaminestimulated acid secretion in isolated parietal cells. Under the same conditions, they were not able to demonstrate potentiation in isolated gastric glands except after a 'prolonged' incubation of 30 to 45 mins.

In our experiments using isolated gastric glands with incubation times of 60 mins, we did not reproduce the potentiation demonstrated by Levine and, in fact, we showed inhibition with increasing ASA concentration. One possible explanation for this inconsistency in results between Levine's isolated parietal cells and our isolated gastric glands is that perhaps the integrity of the gastric gland as a functional unit with its chief cells, mucous cells and endocrine cells, together with the parietal cells, is necessary to show the inhibitory effect of ASA which we have demonstrated. This, however, does not reconcile the inconsistency between the inhibition that we found with glands incubated for 60 mins compared with the potentiation which Levine found with glands incubated for 30 to 45 mins. Levine's hypothesis that ASA potentiates secretion of $\mathrm{H}^{+}$through a mechanism of mobilization of intracellular $\mathrm{Ca}^{2+}$ may be correct, but the level of intraluminal $\mathrm{H}^{+}$depends on both the rate of $\mathrm{H}^{+}$secretion and on the rate of back diffusion of the ions into the cells from the lumen. The rate at which ASA facilitates back diffusion of the ion into the gastric cells may be sufficient to more than compensate for Levine's hypothesized increased secretion of the ion, resulting in a net decrease in the intraluminal $\mathrm{H}^{+}$in response to the ASA.

If the theory of back diffusion of $\mathrm{H}^{+}$ into the gastric mucosal cells is correct, it suggests that mucosal damage by ASA is mediated not so much by changes in intraluminal $\mathrm{pH}$, but perhaps more so by changes in the intracellular $\mathrm{pH} \mathrm{sec}$ ondary to this ionic back diffusion. The mucosal injury still depends on the presence of some intraluminal acid which must provide the source of $\mathrm{H}^{+}$ for back diffusion.

\section{CONCLUSIONS}

We have demonstrated that high concentrations of ASA inhibit basal and stimulated levels of acid secretion by isolated gastric glands. We have also demonstrated that omeprazole is able to inhibit completely the secretagogue effect of histamine on the gastric glands, and that the presence of ASA does not interfere with the ability of omeprazole to inhibit the histamine stimulation of acid secretion. Misoprostol was able to inhibit the histamine stimulation of acid secretion both with and without the presence of ASA to a much lesser degree than the omeprazole. In fact, we have shown that omeprazole inhibits both stimulated and unstimulated levels of acid secretion to a constant level of secretion which is not altered significantly by any histamine or ASA effect.

These results in vitro indicate that omeprazole may be a very effective agent for the prevention and treatment of ASA-induced gastrointestinal mucosal injury if an acidic gastric environment is a prerequisite to this injury as the source of the injurious back diffusing $\mathrm{H}^{+}$ions.

\section{REFERENCES}

1. Soll AF, Kurata J, McGuigan JE. Ulcers, nonsteroidal antiinflammatory drugs, and related matters. Gastroenterology 1989;96:561-8.

2. Choquet A, Leonard A, Magous R, Bali J. Intracellular coupling of prostaglandin inhibition of acid secretion in isolated rabbit gastric 
parietal cells. Biochem Pharm 1990;39:1905-11.

3. Wallmark B, Lorentzon P, Larsson $\mathrm{H}$. The mechanism of action of omeprazole - A survey of its inhibitory actions in vitro. Scand J Gastroenterol 1985;20:37-51.

4. Bigard MA, Isal JP. Complete prevention by omeprazole of aspirin induced gastric lesions in healthy subjects. Gut 1988;29:A712.

5. Daneshmend TK, Stein AG, Bhaskar NK, Hawkey C]. Abolition by omeprazole of aspirin induced gastric mucosal injury in man. Gut 1990;31:514-7.

6. Berglindh T, Obrink KJ. A method for preparin isolated glands from the rabbit gastric mucosa. Acta Physiol Scand $1976 ; 96: 150-9$.

7. Adrian TE, Goldenring JR, Oddsdottir $\mathrm{M}$, et al. A micromethod for the assay of cellular secretory physiology:

Application rabbit parietal cells. Anal Biochem 1989;182:346-52.

8. Graham DY, Agrawas NM, Roth SH. Prevention of NSAID-induced gastric ulcer with misoprostil: Multicentre, double-blind, placebo-controlled trial. 1988;2:1277-80.

9. Graham DY, Stromatt SC, Jaszewski R, White RH, Triadafilopoulos G. Prevention of duodenal ulcer in arthritics who are chronic NSAID users: A multicenter trial of the role of misoprostol. Gastroenterology 1991;100:A75.

10. Robinson M, Mills R, Euler AR. Ranitidine prevents nonsteroidal anti-inflammatory drug-induced duodenal ulcers. Am J Gastroenterol 1990;85:1268. (Abst)

11. Kauffman G. Aspirin-induced gastric mucosal injury: Lessons learned from animal models. Gastroenterology 1989;96:606-14.

12. Romano M, Razandi M, Ivey KJ . Protection of gastric epithelial cel monolayers from a human cell line by omeprazole in vitro. Scand J

Gastroenterol 1989;24:513-21.

13. Konturek SJ, Cieszkowski M, Kwiecien N, Brzozowski T. Gastric antisecretory and protective effects of omeprazole. Gastroenterology 1983;84:1213.

14. Levine RA, Nandi J, King RL. Aspirin potentiates prestimulated acid secretion and mobilizes intracellular calcium in rabbit parietal cells. J Clin Invest 1990;86:400-8.

15. Shea-Donohue T, Steel L, Montcalm-Mazzilli E, Dubois A. Aspirin-induced changes in gastric function: Role of endogenous prostaglandins and mucosal damage. Gastroenterology 1990;98:284-92. 


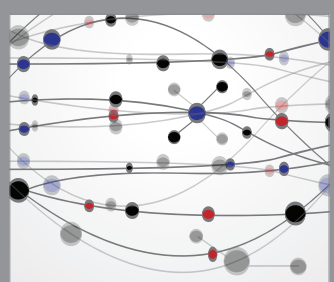

The Scientific World Journal
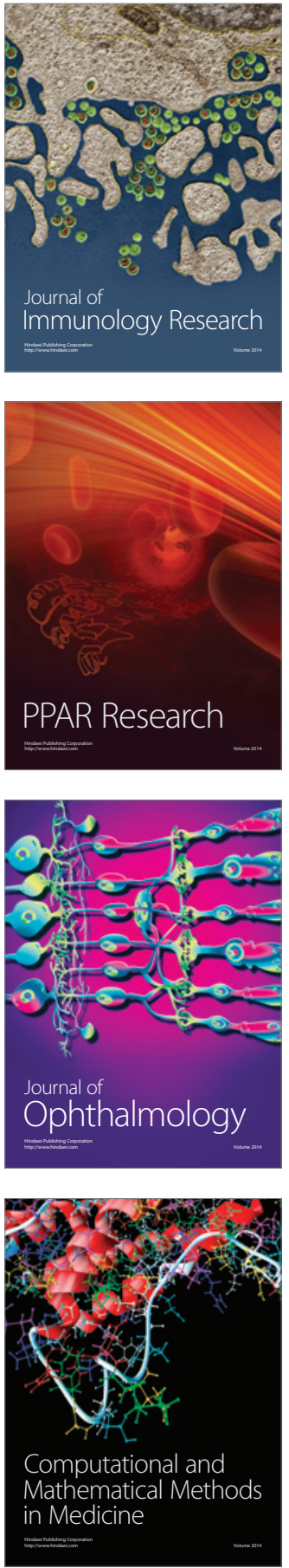

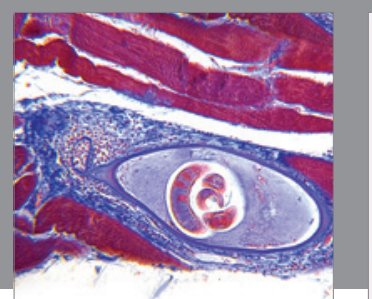

Gastroenterology Research and Practice

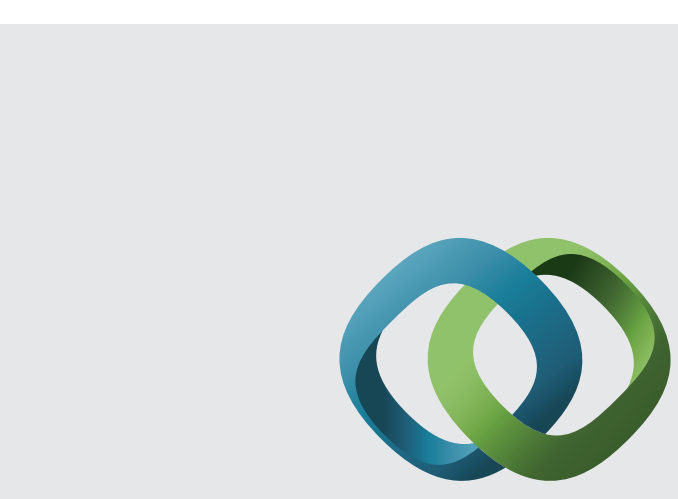

\section{Hindawi}

Submit your manuscripts at

http://www.hindawi.com
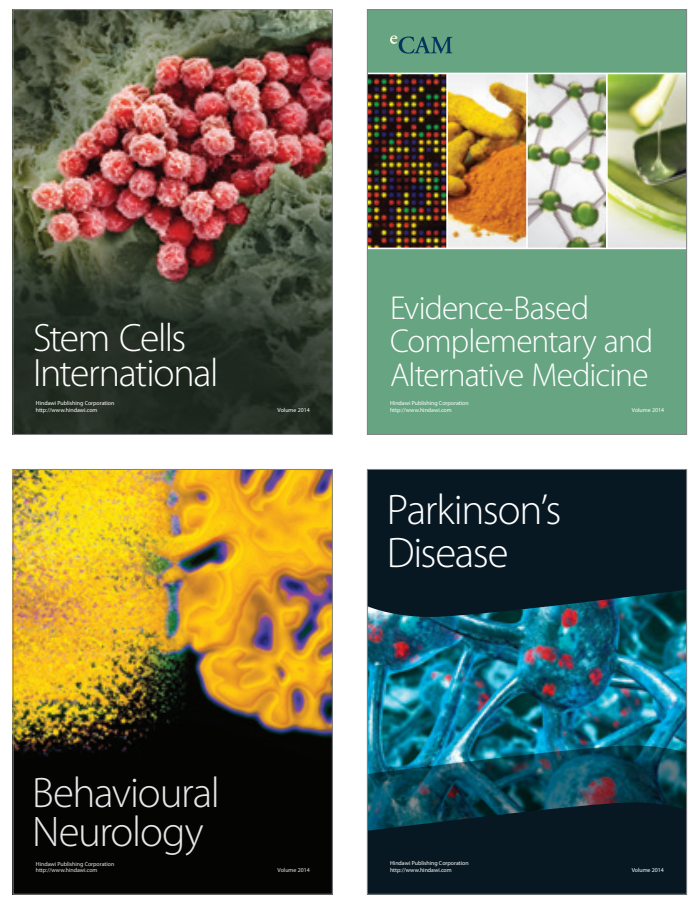
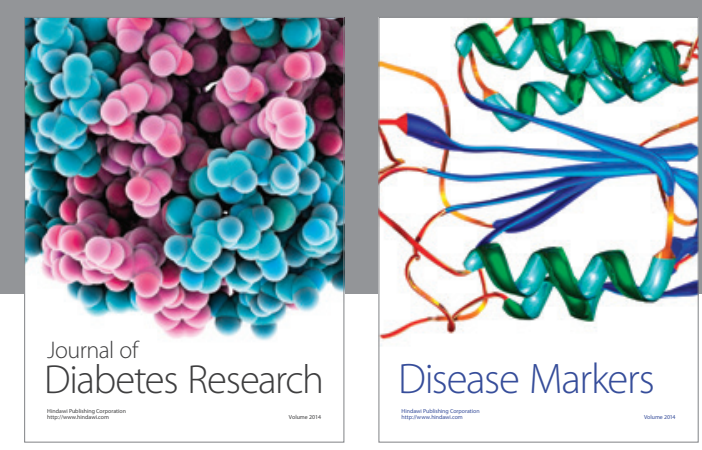

Disease Markers
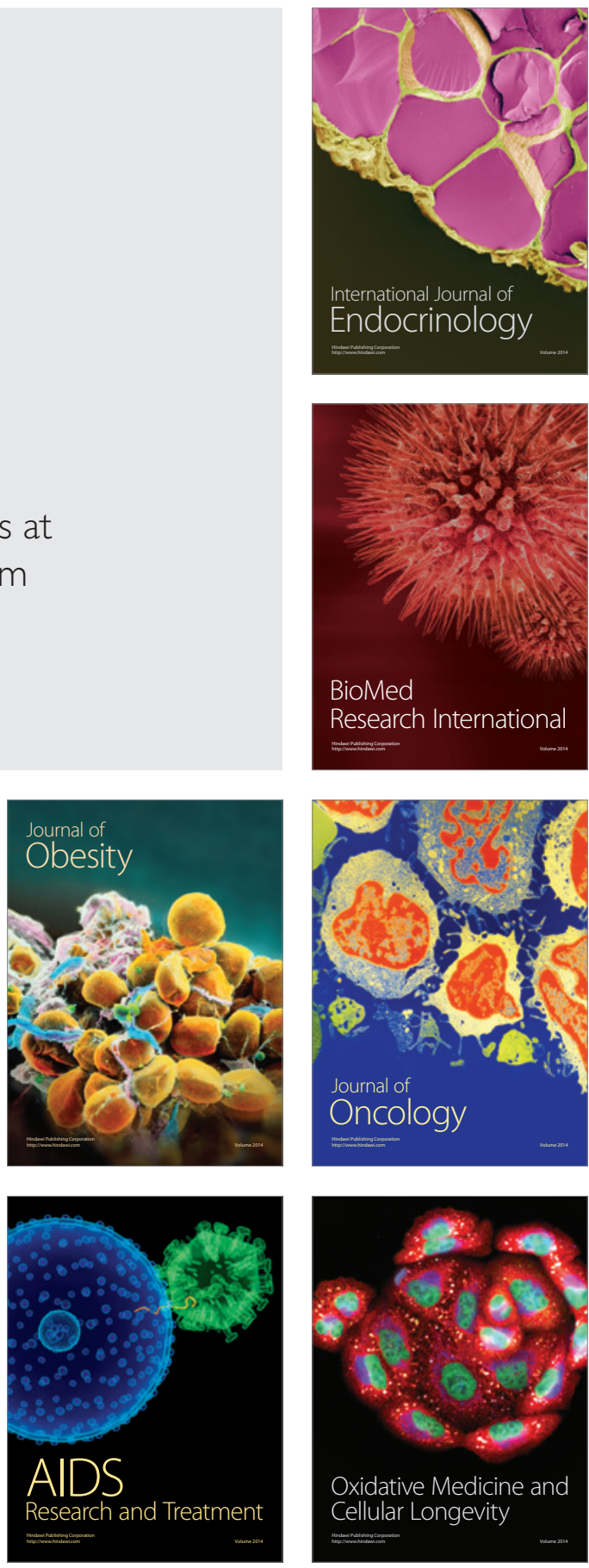